\title{
TOIMINTAKYVYN ARVIOINTIMENETELMIEN KÄYTÖN JA ARKITYÖN TASAPAINOTTELUA KOTIIN VIETÄVISSÄ PALVELUISSA
}

Jenni-Mari Räsänen: YTT, tutkijatobtori, Tampereen yliopisto

jenni-mari.rasanen@tuni.fi

Janus vol. 27 (2) 2019, $x x x-x x x$

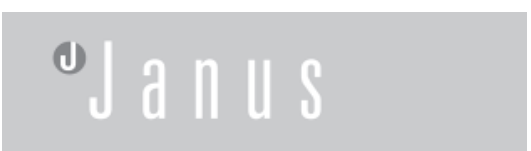

Tiivistelmä

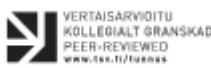

Artikkelissa tarkastellaan toimintakyvyn arviointimenetelmien käytön ja arkityön välistä tasapainottelua kotiin vietävissä, liikkuvissa palveluissa. Tutkimuksen aineistona on yhdeksän työntekijähaastattelua. Analyysi pohjautuu etnometodologiaan. Siinä tarkastellaan, miten haastateltavat jäsentävät ja järkeilevät arviointimenetelmien käyttöä sekä toisaalta puolustavat ja oikeuttavat tavallisesta poikkeavaa käyttöä osana arkityötään. Analyysi osoittaa, että asiakkaiden yksilölliset tilanteet ja erityispiirteet, arviointimenetelmien käytettävyys ja sisällöt sekä asiakastyön rytmi asettavat työntekijöille tarpeen arviointimenetelmien käytön tasapainotteluun arkityössään. Arviointimenetelmien käyttö asiakastilanteissa ja erityisesti asiakkaiden kodeissa vaatii työntekijöiltä sensitiivisyyttä ja tilannekohtaista harkintaa siinä, milloin niitä on sopivaa käyttää ja milloin käyttöä tulee perustella ja selittää asiakkaalle tarkemmin.

\section{JOHDANTO}

Sosiaali- ja terveysalan ammattilaiset ovat yhä enemmän tekemisissä erilaisten arvioinnin välineiden kanssa jokapäiväisessä työssään (esimerkiksi Saario 2011; Günther 2015). Rajavaaran (2007, 12) mukaan erilaiset arviointikäytännöt ovat läsnä miltei kaikissa hyvinvointivaltion palveluissa, toiminnoissa ja etuuksissa, mikä osaltaan pohjautuu lainsäädäntöömme laajalti lisättyihin arvioinnin vaateisiin. Arviointi voidaan ymmärtää monin eri tavoin ja käsitettä myös käytetään monissa eri yhteyksissä (Paasio 2003, 3). Niin ikään arviointivälineillä ja -mittareilla tarkoitetaan eri asioita ja se, mitä niillä eri konteksteissa arvioidaan, vaihtelee (Kivipelto ym. 2013). Asiakirjat ja tietojärjestelmät nähdään yhdenlaisina työntekijöiden sekä palvelujen ja niiden vaikuttavuuden arvioinnin välineinä (Saario 2011; Günther 2015), mutta yhtä lailla myös asiakastyön havainnointi on yhdenlaista arviointia (Günther ym. 2013, 39-40). Arviointia tehdään kaiken aikaa epävirallisesti arkisissa työkäytännöissä, mutta arviointiin sovelletaan yhä enemmän myös systemaattisempia menetelmï (Clarke ym. 2006, 564; Mark ym. 2006). Esimerkiksi Englannissa lastensuojelun kotikäyntityössä (Winter \& Cree 2016, 1185) ja päihdepalveluissa (Cree ym. 2014) käytetään vaikuttavuutta osoittavia mittareita. Myös mielenterveyspalveluissa hoidon tuloksellisuutta ja toipumisen etenemistä arvioidaan erilaisilla mittareilla ja välineillä, joita 
myös kehitetään kovaa vauhtia (Sklar ym. 2013; Haberer ym. 2013).

Arviointia tehdään niin palvelujärjestelmän, organisaatioiden kuin yksilöiden tasolla (Koivula 2012; Mark ym. 2006). Koivulan (2012, 75-78) mukaan asiakastason mittareita käytetään sosiaalipalveluissa vielä vähän eikä niihin ole olemassa riittäviä malleja, välineitä tai tietojärjestelmiä. Näin ollen työntekijöiden asiantuntemusta tarvitaan mittareiden kehittämisessä, jotta voidaan löytää työn onnistumista ja vaikuttavuutta parhaiten kuvaavia mittareita (Koivula 2012; Tickle ym. 2013). Tässä tutkimuksessa tarkastelun kohteena ovat työntekijöiden jäsennykset arviointimenetelmistä ja -mittareista (käytän näistä jatkossa termiä arviointimenetelmät), jotka kohdentuvat asiakkaiden toimintakyvyn arviointiin kotiin $^{1}$ vietävien ja luonteeltaan liikkuvien palveluiden arkityössä. Tutkimukseni paikantuu suuren suomalaisen kaupungin ostopalveluna hankkimiin tuetun asumisen palveluihin sekä kaupungin omaan avohoidolliseen liikkuvan psykiatrian palveluyksikköön. Kyseisissä palveluissa otettiin palvelun tilaajan aloitteesta vuoden 2015 lopulla käyttöön tiettyjä toimintakyvyn arviointimenetelmiä, joiden käytöstä ja käyttömääristä palveluntuottajien tulee raportoida tilaajalle vuosittain (Hankintasopimus 2015). Arviointimenetelmiä valikoitui lopulta yhteensä seitsemän ja ne vaihtelivat muun muassa laajuudeltaan, kustannuksiltaan, kirjaamis- ja mittaamistavoiltaan.

Koska arviointimenetelmien käyttö ohjautui palveluihin "ulkoa päin", on kiinnostavaa tarkastella miten työntekijät puhuvat niiden käytöstä osana työ- tään. Kuten Hartswood ja kumppanit (2003, 263) toteavat, uusien teknologioiden (tässä tapauksessa arviointimenetelmien) vaikutukset työkäytäntöihin ovat usein ennustamattomia ja tulevat näkyviksi vasta niitä käytettäessä. Artikkelini tarkempi tutkimuskysymys on: miten työntekijät tasapainottelevat arviointimenetelmien käytön ja arkipäiväisen työn välillä? Tutkimukseni aineistona on yhdeksän arviointimenetelmiä työssään käyttävien työntekijöiden yksilö- ja ryhmähaastattelua. Analyysini pohjautuu etnometodologiaan, jolloin tarkastelen, miten haastatteluun osallistuvat tuottavat erilaisia tilannekohtaisia selontekoja arviointimenetelmien käytöstä sekä erityisesti niiden tavallisesta poikkeavasta ja/tai odotusten vastaisesta käytöstä tai käyttämättömyydestä osana arkityötään (Scott \& Lyman 1968; Baker 2003). Tulosteni pohjalta teen tulkintaa siitä, miten arviointimenetelmät sopivat osaksi liikkuvaa ja asiakkaan kotona tehtävää työtä.

\section{TOIMINTAKYKY, SEN ARVIOINTI} JA MITTAAMINEN

Toimintakyky voidaan määritellä eri tavoin eikä sille ole olemassa yhtenäistä ja hyväksyttyä käsitteistöä (Voutilainen \& Vaarama 2004, 8). Väljästi ilmaistuna toimintakyky tarkoittaa "ihmisen fyysisten, psyykkisten ja sosiaalisten ominaisuuksien suhdetta häneen kohdistuviin odotuksiin", jolloin toimintakykyä arvioitaessa tarkastellaan ihmisen mahdollisuuksia elää ja toimia suhteessa näihin eri kautta muodostuviin odotuksiin (Lehto 2004, 18). Toimintakyvyn mittaamisen ja arvioinnin tulisi Lehdon $(2004,19)$ mukaan perustua selkeisiin ja useita 
ulottuvuuksia sisältäviin kriteereihin. Esimerkiksi ikääntyneiden palveluissa tarvitaan monipuolinen mittaristo, joka huomioi ikääntyneiden henkilöiden toimintakyvyn eri ulottuvuudet (Voutilainen \& Vaarama 2004, 35). Valittujen toimintakykymittareiden tulisi olla teoreettisesti perusteltuja, luotettavia, päteviä ja käyttökelpoisia (Voutilainen \& Vaarama 2004, 10; Linnakangas ym. 2015, 409). Terveyden ja hyvinvoinnin laitoksen asiantuntijoiden ylläpitämään TOIMIA-tietokantaan on koottu toimintakyvyn arvioinnin mittareita, niiden käyttökelpoisuuteen, pätevyyteen ja toistettavuuteen liittyvää tietoa sekä asiantuntijoiden laatimia toimintakyvyn mittaamisen suosituksia (ks. TOIMIA).

Tuetun asumisen ja liikkuvan psykiatrian palveluihin valikoituneet ${ }^{2}$ arviointimenetelmät ovat paperi- ja/tai sähköisiä kysely- tai haastattelulomakkeita, jotka eroavat sisällöiltään, laajuudeltaan, kirjaamis- ja mittaamistavoiltaan, käyttökustannuksiltaan sekä tieteelliseltä pätevyydeltään. Arviointimenetelmistä osa tuottaa numeerista ja mitattavaa tietoa ja toiset pelkästään tekstimuotoista tietoa. Käytössä olevat arviointimenetelmät ovat mielenterveyskuntoutujan toipumistähti (Mental Health Recovery Star: ks. MacKeith 2011), asumisen, toimintakyvyn ja tarpeiden arviointilomake Asta ${ }^{\mathrm{TM}}$, tavoitteiden asettamiseen ja arviointiin tarkoitettu GAS-menetelmä, toimintakyvyn ja taitojen arviointityökalu Living Skills, PAAVO-itsearviointimenetelmä, Tuva ${ }^{\circledR}$-toimintakykymittari sekä terveyden ja toimintarajoitteiden arviointimittari WHODAS 2.0. (Kirjallisuuslistassa on linkit arviointimenetelmiä kuvaaville sivuille). Tällä hetkellä GAS ja WHODAS 2.0. löytyvät TOIMIAtietokannasta, jossa kerrotaan niiden pätevyydestä olevan riittävästi tieteellistä näyttöä (TOIMIA). Käytössä olevat arviointimenetelmät kohdentuvat erilaisin painotuksin fyysisiin, kognitiivisiin ja psykososiaalisiin tekijöihin. $\mathrm{Ne}$ sisältävät päivittäiseen asumiseen ja toiminnan arviointiin liittyviä osioita, joissa tarkastellaan arjen ja kodin taitoja, sosiaalisia suhteita sekä hygieniaan, vapaa-aikaan ja taloudellisiin asioihin liittyviä kysymyksiä. Osa sisältää myös työhön ja opintoihin liittyviä osa-alueita sekä fyysisiin tekijöihin liittyviä kysymyksiä.Tutkimuksessani ei kuitenkaan eritellä yksittäisten arviointimenetelmien tuottamaa tietoa, sisältöjä ja taustaolettamuksia.

\section{ArViointi JA ARVIOINTIMENETELMäT ASIAKASTYÖN ARJESSA}

On esitetty, että esimerkiksi asiakkaiden hyvinvoinnin muutoksen systemaattinen seuranta standardoitujen mittareiden avulla voi auttaa tunnistamaan toimivia ja vaikuttavia toimintatapoja (Linnakangas ym. 2015; Kivipelto ym. 2013). Erilaisten arviointimenetelmien ja -mittareiden on nähty tarjoavan työntekijöille välineitä asiakkaiden kanssa keskusteluun, asiakkaan ja työntekijän välisen suhteen luomiseen sekä mahdollisuuteen saada uutta tietoa työnsä tueksi (Trauer 2010; Tickle ym. 2013; Kivipelto \& Saikkonen 2013, 318-319). Arviointimenetelmien ja -mittareiden käyttötarkoitukset näyttäytyvät eri tavoin eri kohderyhmien näkökulmista; esimerkiksi palvelun käyttäjien ja palveluntuottajien näkökulmasta niiden tulee tuottaa tietoa asiakkaiden tilanteiden seuraamiseksi 
ja piilossa olevien ongelmien ja tarpeiden havaitsemiseksi sekä olla välineitä, jotka edistävät asiakkaiden toipumista (Trauer 2010, 185). Palvelun rahoittajien näkökulmasta erilaisten mittareiden tulee vuorostaan tuottaa luotettavaa ja pätevää tietoa, sillä heillä on yhä enenevässä määrin tarve saada todisteita hoidon vaikuttavuudesta ja vastinetta rahoilleen (mt., 191) sekä tietoa hoidossa tapahtuneista muutoksista (Mac Keith 2011).

Toisaalta on havaittu, että asiakkailla ja työntekijöillä saattaa olla haasteita sitoutua arviointimenetelmien käyttöön (Korteniemi ym. 2012, 97; Haberer ym. 2013). Työntekijöiden näkökulmasta esimerkiksi mielenterveyden toipumistähti ei välttämättä sovellu käytettäväksi kaikkien asiakkaiden kanssa, sillä asiakkaiden lukutaito, kognitiiviset taidot sekä heidän kykynsä ymmärtää menetelmän sisältämiä käsitteitä ja sen eri vaiheita vaihtelevat (Tickle ym. 2013, 197-198). Simonen (2010; 2017) on tarkastellut etnometodologisen keskustelunanalyysin avulla toimintakyvyn arvioinnin rakentumista vuorovaikutustilanteissa. Hän muun muassa tuo pitkäaikaistyöttömien ja ikääntyneiden sosiaalisen toimintakyvyn arviointitilanteiden analyysin pohjalta esiin, että arviointiin suunnattujen kysymysten suunnittelussa on syytä kiinnittää huomiota yksiselitteisyyteen, jotta ymmärrysongelmilta vältyttäisiin (Simonen 2010). Arviointi ja arviointimenetelmät ovat myös lisänneet työntekijöiden kirjaamistehtäviä ja työtaakkaa ja näin ollen vieneet aikaa varsinaisesta asiakastyöstä (Tobias 2010, 166; Kivipelto \& Saikkonen 2013, 318; ks. myös Pithouse ym. 2009, 607). Saario (2011) osoittaa tutkimuksessaan, kuinka työnteki- jät suhtautuvat arviointikäytäntöihin (erilaisiin työn tuotosten osoittamisiin) niitä noudattaen, vastustaen tai strategisesti tasapainotellen.

Mielenterveys- ja päihdekuntoutuksen vaikuttavuuden arvioinnin mittaamisen on todettu olevan haastavaa, sillä muutoksen kohteena on koko ihmisen elämä, mikä ei palaudu yksittäiseen interventioon tai toimintaan (Väyrynen 2012, 272). Vakavaa mielensairautta sairastavien kohdalla tulee huomioitavaksi toimintakyvyn ja voinnin suurikin vaihtelu, jolloin arviointi tavoittaa yksilön toiminnan ja tunnetilan aina tilannekohtaisesti (Günther ym. 2013, 43). Vaikutusten arviointi ja lopullisten tulosten saavuttaminen eivät käy hetkessä; esimerkiksi päihdeongelmasta toipumisen prosessit ovat yleensä aikaa vieviä ja edellyttävät pitkää seurantaa (Korteniemi ym. 2012, 98). Täten mittaamisen tulisi olla monitasoisempaa, toistuvaa, pieniä askeleita huomioivaa sekä kontekstisidonnaista (Cree ym.2016, 289; Väyrynen 2012, 285). Tutkimuksissa onkin kysytty, miten monimutkaisia ihmiselämän tilanteita, prosesseja ja muutoksia on ylipäänsä mahdollista mitata (Munro 2004; Mac Keith 2011,98; Cree ym. 2016). Sosiaalityössä toteutettuja vaikuttavuuden arviointeja on kritisoitu siitä, että ne jättävät keskeisiä sosiaalityön osa-alueita huomioimatta, kuten ihmisten kanssa työskentelyn taidon, ymmärryksen ja ammatillisen harkinnan merkityksen (Munro 2004, 1093). Työntekijöiden kokemusten mukaan työn onnistumista mittaa useimmiten parhaiten se, miten he ovat onnistuneet ihmissuhdetyöntekijöinä sekä asiakkaiden konkreettisessa auttamisessa (Jokinen ym. 2005, 158; Väyrynen 2012). Sosiaalityössä 
voitaisiinkin puhua "vaikutusten kuvaamisesta", sillä vaikuttavuuden eri ulottuvuuksien näkyväksi tekeminen ja niiden ymmärtäminen ovat haasteellisia (Pohjola 2012, 9-12).

Mittareiden käytön tulee sosiaalialalla olla aina perusteltua ja niiden käyttötarkoitus ja tavoitteet tiedossa. Myös niiden mahdollinen vaikutus asiakastilanteisiin tulee huomioida. (Manssila ym. 2018.) Paasion (2003, 1) mukaan vaikuttavuuden arviointimenetelmien käyttöönotto edellyttää uudenlaisten toimintatapojen oppimista sekä uusien käsitteiden omaksumista, sillä "on aina tärkeää ymmärtää miksi jotain tehdään." Onkin havaittu, etteivät työntekijät välttämättä pidä arviointia mielekkäänä osana asiakaskastyötä, sillä sen merkitys työlle ja kehittämiselle voi näyttäytyä epäselvänä (Korteniemi ym. 2012, 97-98).

\section{TUTKIMUSKONTEKSTIN KUVAUS}

Tutkimukseni kontekstina ovat suuren suomalaisen kaupungin ostopalveluna hankkimat tuetun asumisen palvelut (yhteensä 16 palveluntuottajaa) sekä kaupungin oma avohoidollinen liikkuvan psykiatrian yksikkö, joissa kaikissa tehdään liikkuvaa, asiakkaiden koteihin suuntautuvaa työtä. Tuetun asumisen palvelu on sosiaalihuoltolain (21』) mukaista asumispalvelua, joka kohdentuu henkilöihin, jotka tarvitsevat tukea itsenäisessä asumisessa tai siihen siirtymisessä. Asumista tuetaan sosiaaliohjauksella ja muilla sosiaalipalveluilla (SHL 21S). Avohoidollinen liikkuvan psykiatrian yksikkö kuvataan kaupungin verkkosivuilla terveydenhuollon palveluna, joka tarjoaa apua tilanteisiin, joissa potilas ei kykene käymään psykiatrian vastaanotolla, hänen sairautensa on pahenemisvaiheessa tai hän on sairaalahoidon jälkeisessä toipumisvaiheessa. Mielenterveys- ja päihdetyön valtakunnallisissa suosituksissa ensisijaisena tavoitteena on turvata asiakkaan asuminen tavallisessa asunnossa, jossa hänellä on myös mahdollisuus valita "elämänhallintaa, toimintakykyä ja osallisuutta lisääviä tarvelähtöisiä ja vaikuttavia tukitoimia" (Mielenterveys- ja päihdesuunnitelma 2012, 50).

Tuetun asumisen palvelujen asiakasryhmään lukeutuu pääasiassa mielenterveys- ja päihdekuntoutujia, mutta myös 18-21-vuotiaita jälkihuollossa olevia nuoria aikuisia sekä vähäisemmässä määrin lapsiperheitä ja neuropsykiatrisista häiriöistä kärsiviä henkilöitä. Palvelukuvauksen mukaan asiakkaat asuvat omassa kodissaan ja saavat tukea palveluntuottajalta. Asiakkaiden palvelutarpeen on katsottu liittyvän asumisen tukeen, ohjaukseen ja neuvontaan sekä arjen elämänhallinnan, sosiaalisen ympäristön ja riippuvuuksien hallintaan. Työntekijän roolina näissä palveluissa on tukea ja ohjata asiakasta arkielämään liittyvissä asioissa; ruokahuollossa, terveydenhoidossa, asioinnissa, taloudellisten etuuksien hakemisessa, vuokranmaksussa, siisteydessä ja hygieniassa. Asiakkaat ohjataan tuetun asumisen palveluihin kaupungin asiakasohjausyksiköiden kautta, joissa tehdään palvelutarpeen arvio. Palvelupyynnön tekee asiakkaan asioista vastaava sosiaalityöntekijä tai terveydenhuollon työntekijä. (Palvelukuvaus 2015.) Liikkuvan psykiatrian palvelukuvauksen mukaan asiakaskuntaan lukeutuu henkilöitä, joilla on esimerkiksi skitsofrenia tai 
muu psykoottinen häiriö. Palveluihin päästäkseen asiakas tarvitsee lähetteen.

\section{TUtKIMUSTEHTÄVÄ, AINEISTO}

JA ANALYYSIN TOTEUTUS

Tutkimuskysymykseni on: miten työntekijät tasapainottelevat arviointimenetelmien käytön ja arkipäiväisen työn välillä? Tutkimukseni nojaa etnometodologiaan, jolloin tutkimuskatseeni kohdentuu arkipäiväisiin tilanteisiin ja siihen, miten asioita jäsennetään ja tehdään niissä jatkuvasti ymmärrettäviksi (Garfinkel 1967). Analyyttisenä käsitteenä käytän selontekoa (account), joka on etnometodologiaan pohjautuva arkielämän järkeilytapa ja menetelmä, jonka avulla ihmiset jäsentävät ja pitävät yllä todellisuuttaan (Garfinkel 1967). Selontekoja annetaan myös tavallisesta poikkeavissa tilanteissa, jolloin niillä pyritään ylittämään toiminnan ja sen odotusten välistä kuilua ("bridging the gap between action and expectations") (Scott \& Lyman 1968, 46). Tutkimuksessani tällaisia ovat tilanteet, joissa arviointimenetelmien käyttämättömyyttä ja/ tai odotusten vastaista käyttöä arkisessa työssä oikeutetaan tai puolustetaan. Puolustukset ovat selontekoja, joilla toiminnan myönnetään olevan sopimatonta tai tavallisuudesta poikkeavaa, mutta johtuvan jostakin ulkopuolisesta tekijästä (Austin 1961, 123-124; Scott \& Lyman 1968, 46-47). Oikeuttaminen on vuorostaan tapa neutralisoida tavallisesta poikkeavaa toimintaa ja sen seurauksia esimerkiksi sillä, että tilanne edellytti tai salli toisenlaisen toiminnan (Scott \& Lyman 1968, 47, 51).

Kuten aiemmat tutkimukset osoittavat, erilaiset arviointimenetelmät ja -mittarit ovat ammattilaisille tärkeitä ja hyödyllisiä välineitä, mutta ne ovat tuoneet myös monenlaisia pulmia arkiseen työhön. Koska arviointimenetelmien käyttö ohjautui tutkimuksessani mukana oleviin palveluihin ulkoa päin, tilaajan edellyttämänä, on erityisen tärkeää tarkastella, miten työntekijät jäsentävät niiden käyttöä osana työtään. Palveluntuottajat ovat hankintasopimuksen (2015) myötä sitoutuneita raportoimaan tilaajalla vuosittain arviointimenetelmän käyttökokemuksista. Palveluntuottajia pyydetään vuosittain kuvaamaan arviointimenetelmien käyttömäärät sekä perustelut sille, jos arviointimenetelmiä ei ole käytetty. Niin ikään heitä pyydetään kertomaan, minkä mittaisen ajanjakson ajan menetelmää on käytetty ja miten asiakkaan tavoitteet sekä työntekijän ja asiakkaan yhteinen tavoite on löydetty ja asetettu. Onkin kiinnostavaa tarkastella missä määrin nämä odotukset heijastuvat työntekijöiden puheessa ja asettavatko ne tarpeen perustella ja tasapainotella arviointimenetelmien käyttöä (ks. Räsänen \& Saario 2017).

Tutkimusaineistonani on yhdeksän työntekijähaastattelua. Etnometodologisissa tutkimuksissa haastattelut nähdään vuorovaikutuksen ja tiedon tuottamisen konteksteina, joissa esiintyy paljon selontekoja. Näissä konteksteissa haastatteluun osallistuvat kuvaavat, selittävät tai muulla tavoin järkeilevät niitä toimintoja ja asioita, joista he puhuvat tai joihin he puheessaan viittaavat. (Baker 2003, 399.) Haastatteluista neljä oli yksilöhaastatteluja ja loput ryhmähaastatteluja, joissa oli tutkijan lisäksi läsnä 2-5 henkilöä. Haastattelut on toteutettu kevään ja alkukesän 2017 aikana. Lähettämässäni haastattelupyynnössä ${ }^{3}$ esitin toiveen toteuttaa joko ryhmä- 
tai yksilöhaastatteluja ja että läsnä olisi henkilöitä, jotka ovat käyttäneet arviointimenetelmiä työssään. Haastatteluun osallistuneissa yksiköissä käytettiin kaikkiaan kuutta eri arviointimenetelmää. Toteutin kaikki haastattelut työntekijöiden omissa toimipisteissä. Haastatteluaineiston keruuta edelsivät palveluiden hankinnasta vastaavien henkilöiden (tilaajien) kanssa käydyt neuvottelut, palveluntuottajien vuosittain (2016 ja 2017) tilaajalle laatimat arviointimenetelmien käyttöä koskevat raportit sekä palvelujen tilaajien ja palveluntuottajien yhteiset arviointimenetelmiä koskevat keskustelutilaisuudet vuosina 2016-2018. Nämä syvensivät tutkimusaihetta ja -kontekstia koskevaa ymmärrystäni sekä toimivat haastattelurungon suunnittelun tukena.

Haastattelut rakentuivat teemoittain. Aluksi pyysin työntekijöitä kuvaamaan työnsä keskeisiä piirteitä, käytössä olevaa toimintakyvyn arviointimenetelmää sekä mahdollisia syitä sen valintaan. Lisäksi kysyin käytössä olevan arviointimenetelmän hyötyjä sekä haittoja oman työn, asiakkaan, tiedon vaihdon ja yhteistyön näkökulmista. Kysyin myös arviointimenetelmän käyttöön liittyvästä koulutuksesta, käyttöönottoon liittyvistä alkuodotuksista sekä käyttöön liittyvistä tulevaisuuden suunnitelmista. Aineiston analyysi käynnistyi sisällöllisellä jäsentelyllä sen mukaan, millaisia asioita työntekijät liittävät arviointimenetelmien hyötyihin ja toisaalta niiden asettamiin esteisiin ja haasteisiin sekä sen mukaan, millaista tietoa arviointimenetelmät työntekijöiden mukaan tuottavat. Tämä oli luonteva lähtökohta, sillä haastattelurunko jakautui kyseisiin näkökulmiin. Nämä olivat myös kaik- kia haastatteluja läpäiseviä, yleisiä teemoja.

Sisällöllisen jaottelun jälkeen pureuduin tarkemmin niihin haastattelujen kohtiin, joissa työntekijät kuvaavat arviointimenetelmien hyötyjä (missä tilanteissa ne ovat toimivia ja käytettäviä), mutta tuovat esiin myös niiden asettamia haasteita ja pulmia (milloin ne eivät toimi tai sovi työhön tai ole käytettäviä). Näissä kohdissa he tulkintani mukaan tasapainottelevat arviointimenetelmien käytön, käyttöön liittyvien odotusten sekä arkipäiväisessä työssä eteen tulevien tilanteiden välillä. He jäsentävät ja järkeilevät arviointimenetelmien käyttöä sekä oikeuttavat ja puolustavat tavallisesta poikkeavaa käyttöä eri tavoin. Useimmiten muut osallistujat (mikäli läsnä useita) joko vahvistavat tai tekevät eroa toinen toistensa puheenvuoroihin esimerkiksi "totta", "toisaalta", "mutta" ja "kuitenkin" ilmaisuin. Erityisesti ryhmähaastattelut antavat mahdollisuuden tarkastella asioiden rakentamista osallistujien välisenä yhteistyönä (ks. Juhila ym. 2010). Arviointimenetelmien käytön ja arkityön välistä tasapainottelua esiintyy jokaisessa haastattelussa, mutta enemmän niissä, joissa arviointimenetelmää kuvataan irrallisena ja/tai sen käyttöön liittyvät pelisäännöt ovat epäselvät. Tasapainottelupuhetta sisältävää aineistoa kertyi litteroituna yhteensä 61 sivua kokonaisaineiston ollessa 138 sivua (fontti Calibri, fonttikoko 12, riviväli 1).

Arviointimenetelmien käytön ja arkityön välinen tasapainottelu jakautuu aineistossani kolmeen teemaan: 1) arviointimenetelmät ja asiakkaiden yksilölliset tilanteet (31 otetta), 2) arviointimenetelmät ja niiden käytettävyys 
(33 otetta) ja 3) arviointimenetelmät ja asiakastyön rytmi (8 otetta). Kuvaan seuraavassa luvussa tarkemmin, millaista puhetta näiden teemojen alla esitetään sekä analysoin yksityiskohtaisemmin niissä tuotettuja selontekoja.

Tutkimuseettisestä näkökulmasta on tärkeää mainita, että tutkimusluvat myönnettiin jokaisesta haastatteluun osallistuneesta organisaatiosta joko toiminnasta vastaavan henkilön tai virallisen tutkimuslupaprosessin kautta keväällä 2017. Palvelujen hankinnasta vastaavan kaupungin tutkimuslupa myönnettiin marraskuussa 2016. Vaikka viralliset tutkimusluvat olivat olemassa, pyysin ja varmistin jokaisessa haastattelutilanteessa vielä erikseen työntekijöiden suostumuksen osallistumisestaan tutkimukseen. Tutkimuksen toteuttamista edelsivät useat palvelujen hankinnasta vastaavien henkilöiden kanssa käydyt neuvottelut aineiston keruusta, tutkimuksen tarkoituksesta sekä hyödyllisyydestä käytännön työlle. Olen osallistunut tuetun asumisen palveluntuottajille järjestettyihin tilaisuuksiin, joissa olen kertonut tutkimukseni tavoitteista ja tutkimusprosessin eri vaiheista. Haastateltavien tunnistettavuuden häivyttämiseksi olen poistanut haastatteluotteista organisaatioiden, paikkakuntien sekä käytössä olevien arviointimenetelmien nimet.

Tutkimuksessani on mukana monenlaisia palveluntuottajia, joiden asiakaskunnat ja käytössä olevat arviointimenetelmät vaihtelevat. Tutkimuksessani on tarkoitus tuoda näkyväksi työntekijöiden jäsennyksiä ja järkeilytapoja siitä, miten arviointimenetelmät sopivat kotona tehtävään ja liikkuvaan työhön. Näin ollen tutkimukseni ulkopuolelle rajautuvat yksittäisten arviointimenetelmien ominaisuuksien, taustaolettamusten, sisältöjen sekä käytettävyyden erittely ja arviointi.

\section{ArviointimenETELmIEN KÄYTÖN TASAPAINOTTELUA ASIAKASTYÖN ARJESSA}

Analysoin seuraavaksi tarkemmin arviointimenetelmien käytön ja arkityön välistä tasapainottelua kuvaavia aineisto-otteita. On syytä huomioida, että teemat ilmenevät aineistossa limittäin ja samoja otteita voidaan lukea useiden teemojen alle. Työntekijät voivat puhua samassa otteessa esimerkiksi asiakkaiden yksilöllisistä tilanteista, arviointimenetelmien käytettävyydestä ja asiakastyön rytmistä. Tämä ilmenee myös esimerkkiotteissa. Kaikki artikkelissa esitetyt otteet ovat eri organisaatioista, joten niiden asiakasryhmissä ja käytössä olevissa arviointimenetelmissä on eroja.

Arviointimenetelmät ja asiakkaiden $y k s i-$ lölliset tilanteet

Haastatteluista voidaan paikantaa 31 kohtaa, joissa asiakkaiden yksilölliset tilanteet asettavat työntekijöille tarpeen tasapainotella arviointimenetelmien käytön, käyttämättömyyden ja/ tai odotuksista ja tavallisuudesta poikkeavan käytön välillä. Yksilölliset tilanteet viittaavat asiakkaiden vaihteleviin tarpeisiin, lähtökohtiin ja toimintakykyyn.

Esimerkkiote on tuetun asumisen palvelusta, joka on suunnattu neuropsykiatrisista häiriöistä kärsiville aikuisille. Haastattelussa on läsnä kolme työntekijää, mutta otteessa heistä puhuu kaksi (T1 ja T2). Otteessa ilmenee arviointimenetelmän käytön perustelua ja tasa- 
painottelua asiakas-työntekijävuorovaikutuksessa:

\section{Ote 1}

T2: (...) tää ((arviointimenetelmä)) saattaa jotain ihan hirveesti ahdistaakin, että tämmösen kans menee siihen varsinkin, kun aattelee että se ensimmäinen, muutamat käynnit niin menee siihen että, että tutustutaan ja tulee se vuorovaikutussuhde ja sitten ylipäätään kun mennään sinne ihmisen kotiin, niin sitten että ei sinne voi mennä tämmösen lomakkeen kanssa että "tehdäänpä tämä”

T1: Sen takii sitä ei voi ensimmäisillä käynneillä vaan se pitää ekana luoda se suhde.

T2: Mmm-m. Et se niinku, nää on niitä tekijöitä jotka näille sosiaalisesti herkille, meijän asiakaskunnalle ni on just niitä, jotka on sit niitä poistyöntäviä juttuja, että sit se täytyy valita hyvin se hetki, ennakoida sitä. Mieluummin just niin että "joo että tehdään seuraavalla kerralla semmonen, semmonen ihan mikä meijän kuuluu tehdä" ja sitten tota käydä siellä ((asiakkaan kotona)). T1: Joku pelkää tota paperipinoo niin sillon lähetään pienemmissä erissä ja niin poispäin. Ja joillekin se on sitten taas turva ja tuki että "tämä asia on mustaa valkosella" (...)

T2 kuvaa ensimmäisessä vuorossa tilanteita, joissa arviointimenetelmän käyttö saattaa "hirveesti ahdistaakin" asiakkaita ja kuinka alussa ensin tutustutaan asiakkaaseen ja luodaan hänen kanssaan "vuorovaikutussuhde". Tämän jälkeen työntekijä tuo esiin asiakkaan kodin arviointimenetelmän käyttökontekstina. Kotiin ei voi mennä lomakkeen kanssa ja todeta: "tehdäänpä tämä", jonka T1 vahvistaa perustelemalla: "pitää ekana luoda se suhde". Tämän jälkeen vuorossa kolme T2 oikeuttaa arviointimenetelmän käytön siirtämistä hiukan myöhempään ajankohtaan heidän asiakaskuntansa erityispiirteillä: "sosiaalisesti herkät", joille arviointimenetelmät voivat olla "poistyöntäviä juttuja". Hän jatkaa, että työntekijöiden ammattitaitoon kuuluu valita oikea hetki ja tuottaa asiakkaalle ennakkotietoa siitä, milloin arviointilomaketta tullaan käyttämään. Hän myös etäännyttää lomakkeen käyttämiseen liittyvää vastuuta pois työntekijöistä itsestään (Scott \& Lyman 1968, 47) oikeuttamalla asiakkaalle arviointilomaketta jonakin "mikä meijän kuuluu tehdä". Neljännessä vuorossa T1 vahvistaa asiakaskunnan erityisyyttä todeten, että jotkut saattavat "pelätä paperipinoa", minkä vuoksi on syytä edetä arviointimenetelmän käyttämisessä "pienemmissä erissä”. Hän jatkaa, että asiakaskunnassa on myös variaatiota, sillä joillekin asioiden laittaminen "mustaa valkosella" tuo tukea ja turvaa, millä hän vuorostaan perustelee arviointimenetelmän hyödyllisyyttä.

Työntekijöiden puhe osoittaa, että arviointimenetelmien käyttöä tulee sovittaa aina asiakkaan yksilölliseen tilanteeseen ja erityispiirteisiin. Myös asiakkaan koti arviointimenetelmän käyttökontekstina tulee huomioitavaksi arviointimenetelmää käytettäessä. Työntekijöiden tehtäväksi on tullut myös perustella ja oikeuttaa arviointimenetelmän käyttöä asiakkaille. Työntekijöiden puheesta voidaan niin ikään tulkita, että arviointimenetelmään liittyy odotus sen käytöstä asiakassuhteen alussa ja kuinka työntekijät rakentavat keskinäisessä vuorovaikutuksessa selontekoja (ks. Baker 2003, 400) tästä poikkeavasta toiminnasta. 
Arviointimenetelmät ja niiden käytettävyys asiakastyössä

Arviointimenetelmien käytettävyys suhteessa asiakastyön arkeen tulee puhutuksi 33:ssa haastattelukohdassa. Näissä tilanteissa työntekijät tasapainottelevat sen suhteen, miten arviointimenetelmien kysymykset ja sisällöt kohdentuvat vaihtelevasti asiakkaille. Asiakkailla on erilaisia mahdollisuuksia ymmärtää, tulkita ja hahmottaa arviointimenetelmien sisältämiä käsitteitä, arviointiasteikkoja ja/tai kysymyksiä. Arviointilomakkeet ovat toisinaan liian pitkiä ja raskaita, mutta ne voivat olla myös tärkeitä asioiden ja kokonaisuuksien kartoittamisen, havaitsemisen, puheeksi ottamisen ja muistiin palauttamisen välineitä.

Esimerkkiotteessa on läsnä kaksi työntekijää (T1 ja T2). He työskentelevät tuetun asumisen palvelussa, joka kohdentuu mielenterveys- ja päihdekuntoutujille. Ote havainnollistaa arviointimenetelmän sekä siihen laadittavien asiakaslähtöisten tavoitteiden hyödyllisyyden, mutta toisaalta se tuo esiin niiden pulmallisuuden arkisessa työssä.

Ote 2

T2: (...) haastattelulomakkeena tää ((arviointimenetelmälomake)) on hyvä koska tää tavallaan kattaa koko ihmisen elämän ja siitä on sitten hyvä ruveta rakentaa sitä suhdetta siihen asiakkaaseen, että kun yhessä laitetaan paperille se, ett mitä ne tavotteet vois olla niin (...) sitten voi myöhemmin palata, mutta ((naurahtaa)) ne ((tavoitteet)) saattaa sitten muuttuakin ihan viikon sisään tai kahen viikon sisään ja siinä tulee sitten niitä haasteita.
T1: (...) meiän asiakasryhmä on muutenkin haastavaa se, että mitä he sanoo ensimmäisen kuukauden aikana, sanooko he ensimmäisen kuukauden aikana mitään ((naurahtaa)), vastaako he kysyttäessä. Ja kun tähän ((arviointimenetelmään)) kumminkin haetaan asiakaslähtöstä tavotetta, ett mä en voi pistää sinne, että sun tavote on siivota tää kämppä jos se kämppä on ihan pommi, vaan se (...) pitää lähtee siitä asiakkaasta. Ett voi mennä ensimmäinen kuukausi, kaks jopa kolme ennen ku se asiakas edes löytää niitä mitä hän (...) oikeesti omasta mielestään kokee tavotteeksi. Ja se tavote -sana on aina vähän semmonen, tavote on semmonen mitä arvioidaan ja sit kun se asetetaan se rima johonkin niin mitä, jos en mä sit ylläkkään siihen. Ja sit koska suurimmalla osalla asiakkaista on kumminkin paljon pettymyksiä elämässä, niin tää on myös yks semmonen mikä aiheuttaa vähän sellasia paineita siitä, ett mitä jos, ett apua, että mä en ollukkaan siivonnu tiistaina ett nyt niin ku mitäs nyt sitten ja näin ja se saattaa viedä mielialaa tosi paljon alaspäin mikä on sitten taas että miten me otetaan työntekijöinä se sitten haltuun se tilanne ett ei tää oo mikään semmonen vakava asia vaan että se selkeyttää.

T2: Et aina kun laitetaan jotain paperille ja jostain tavotteista, niin asiakkaat olettaa, että niitten täytyy tehdä jotain suurta

T1: Kyllä

T2 kuvaa ensimmäisessä puheenvuorossaan arviointimenetelmän hyödyllisyyttä: se kattaa koko ihmisen elämän, sen avulla voidaan alkaa rakentaa suhdetta asiakkaaseen sekä laittaa paperille yhdessä hänen tavoitteitaan, joihin voidaan aina palata. Tämän jälkeen hän 
kuitenkin esittää tätä tilannetta horjuttavan tilanteen: "mutta ne tavoitteet saattaa sitten munttuakin ihan viikon sisään (...)”. T1 vahvistaa toisessa vuorossa kuvausta asiakasryhmän "haastavuudesta": ei ole varmuutta siitä, mitä asiakas sanoo vai sanooko hän mitään ensimmäisen kuukauden aikana tai missä ajassa asiakkaan on mahdollista asettaa omia tavoitteitaan. Näillä työntekijät puolustavat tavallisesta poikkeavaa arviointimenetelmän käyttöä, jossa asiakaslähtöisten tavoitteiden asettaminen ei onnistu.

T1 tarttuu myös tavoite-sanaan ja sen pulmallisuuteen asiakkaiden näkökulmasta. Tavoitteet ja niiden saavuttaminen saattavat asettaa asiakkaille paineita, mitä hän perustelee asiakaskunnan erityispiirteillä: asiakkaat ovat kokeneet paljon "pettymyksiä" elämässä. Mikäli asiakkaat eivät pääse asetettuihin tavoitteisiin, se voi "viedä mielialaa tosi paljon alaspäin". Tällöin työntekijän tehtäväksi tulee ottaa tilanne haltuun ja asettaa se mittasuhteisiinsa: "ei tää oo niinku mikään semmonen vakava asia vaan että se selkeyttää." Vuorossa kolme T2 vahvistaa tavoitteiden asettamisen pulmallisuuden ja siitä asiakkaille aiheutuvat paineet, jonka T1 edelleen lopussa vahvistaa: Kyllä. Työntekijöiden puheesta voidaan tulkita odotus asiakaslähtöisten tavoitteiden asettamisesta, minkä ongelmallisuutta he puolustavat ja oikeuttavat asiakkaiden vaihtelevalla voinnilla. Työntekijöiden tulee olla valppaina sille, milloin arviointimenetelmää on sopivaa käyttää, millaisia käsitteitä asiakkaiden kanssa käytetään ja milloin käyttöä tulee perustella asiakkaalle.
Arviointimenetelmät ja asiakastyön rytmi

Arviointimenetelmät ja asiakastyön rytmi tulee haastatteluissa esiin kahdeksassa kohdassa. Näissä tilanteissa työntekijät tasapainottelevat sen suhteen, millaisin väliajoin ja kuinka monen asiakkaan kanssa toimintakyvyn arviointia on mahdollista tehdä. Arviointimenetelmän käyttöä tietyssä ajassa ja rytmissä (esimerkiksi kaikkien asiakkaiden kanssa tietyin väliajoin) voivat horjuttaa asiakkaiden vaihtelevat tilanteet ja elämänrytmit, asiakassuhteiden pituudet ja työntekijöiden työlle asetetut reunaehdot.

Aineisto-otteessa kaksi työntekijää (T1 ja T2) keskustelee toimintakyvyn arviointimenetelmän käyttöön liittyvistä aikarajoista ja käyttömääristä. Haastattelu on tehty tuetun asumisen palvelussa, jonka asiakkaat ovat mielenterveyskuntoutujia. Ote alkaa T2:n kuvauksella arviointimenetelmän käyttämisestä tuen alkuvaiheessa:

Ote 3

T2: Toi ((toimintakyvyn arviointilomake)) siis tehdään tosiaan palveluitten alkuvaiheessa. (...) meillä asiakkaat, kun tulee niin saattaa olla esimerkiks jo tiedossa, että tää ei oo kovin pitkäaikanen asiakas tai (...) sit taas se että "tää nyt on teillä palvelus muutaman kuukauden", niin että ei voida ajatella että "no palataanpa asiaan puolen vuoden tai vuoden päästä”. Mut sitten taas (...) meillä asiakkaiden toimintakyky on myöskin semmonen, mikä ilman mittaristoakin osataan jo arvioida ((naurahtaa)) että (...), minkä tyylistä se on (...) vähän asiakaskohtasestikin,

T1: tarpeen mukaan. 
T2: ..niin niin asiakaskohtasesti. Toki pyrimme säännöllisyyteen, että esimerkiks vähintään kerran vuodessa, puolivuosittain ois hyvä ((tehdä toimintakyvyn arviointi)).

T1: Mutta asiakkaat myös väsyy.

T2: Se on ihan totta.

T1: ..siihen sitten (...) ja mennään kuitenkin hänen ((asiakkaan)) kotiinsa. Myös sitten se, että meil on aika paljon sen tyylisiäkin asiakkaita jotka epäilee kovasti (...) tarkoitusperiä (...)

Otteen alussa T2 kuvaa toimintakyvyn arvioinnin ajoittamisen palveluiden alkuvaiheeseen, sillä asiakkuudet eivät välttämättä ole kovin pitkiä. Hän jatkaa, että lyhyet asiakkuudet myös estävät arviointiin palaamisen "puolen vuoden tai vuoden päästä.". Hän myös kuvaa ammattilaisten kykyä arvioida toimintakykyä ilman mittaristoakin ja kuinka toimintakyvyn arviointia tehdään asiakaskohtaisesti. Toisessa vuorossa T1 vahvistaa asiakaslähtöisyyden toteamalla: "tarpeen mukaan". T2 vielä jatkaa, ettei arviointi ole sattumanvaraista, vaan "toki pyrimme säännöllisyyteen." Vuorossa neljä T1 kuitenkin oikeuttaa säännöllisestä rytmistä poikkeavaa käyttöä asiakkaiden voinnilla: "mutta asiakkaat myös väsyy", jonka T2 vahvistaa: "se on ihan totta". Hiukan tämän jälkeen T1 kuvaa "mennään kuitenkin hänen ((asiakkaan)) kotiinsa" ja kuinka asiakkaista useat "epäilee kovasti (...) tarkoitusperiä.” Nämä oletettavasti asettavat jännitteitä toimintakyvyn arviointimenetelmän käyttöön. Otteen jälkeen T1 jatkaa kuitenkin kuvaamalla, että heillä käytössä oleva arviointimenetelmä on sopivan mittainen ja sen avulla työntekijät pääsevät keskustelemaan asiakkaan tilanteen kannalta tärkeistä asioista.
T2:n puheesta on tulkittavissa odotus säännöllisestä, tietyin väliajoin tapahtuvasta toimintakyvyn arvioinnista,johon he työssään pyrkivät. Tämän toteutumiseen arkisessa työssä asettavat jännitteitä hänen ja T1:n kuvaamat esimerkit ja "todisteet" elävästä elämästä (Saario ym. 2015). Näitä ovat lyhyet asiakassuhteet ja asiakkaiden väsyminen. Myös arvioinnin tarkoitusperien epäily sekä työskentely asiakkaan kotiolosuhteissa asettavat toimintakyvyn arvioinnille omat pulmansa. Arviointimenetelmä on kuitenkin osoittautunut myös hyödylliseksi työvälineeksi. Otteessa tulee esiin tasapainottelu arviointimenetelmän käytön ajankohdan, säännöllisyyden sekä asiakastyön rytmin ja asiakkaiden voinnin välillä.

\section{LOPUKSI}

Toimintakyvyn arviointimenetelmien käyttöön liittyy sekä arkityötä tukevia että sitä haastavia tekijöitä, joiden välillä työntekijät tasapainottelevat arkipäiväisessä työssään. Asiakkaiden yksilölliset tilanteet, arviointimenetelmien käytettävyys, sisällöt sekä asiakastyön rytmi asettavat tarpeita arviointimenetelmien käyttämättömyyden ja/tai odotuksista poikkeavan käytön väliseen tasapainotteluun. Niin ikään tasapainotteluun liitetään työskentely asiakkaiden kodeissa. Haastatteluotteissa sekä haastatteluissa kauttaaltaan on nähtävissä, miten nämä ulottuvuudet tulevat useissa kohdissa esiin ja kietoutuvat myös yhteen.

Haastattelupuheesta voidaan tulkita, että työntekijät huomioivat työssään ensisijaisesti asiakkaiden yksilölliset tilanteet ja erityispiirteet sekä pyrkivät sopeuttamaan arviointimenetelmien 
käytön niihin. Työntekijöillä on asiakkaiden arkeen ja elämäntilanteisiin liittyvää tietoa ja "todisteita" (Saario ym. 2015), joilla he puolustavat ja oikeuttavat tavallisesta poikkeavaa arviointimenetelmien käyttöä. Arviointilomake on tärkeä apuväline, joka voi olla asiakkaalle tuki ja turva, virittää monenlaisia keskusteluja sekä auttaa asiakkaita hahmottamaan mistä kaikesta heidän arkensa ja elämänsä lopulta koostuvatkaan. Pulmia ilmenee, mikäli arviointilomakkeen kysymykset eivät sovellukaan kohderyhmälle tai siinä käytetyt käsitteet ovat monitulkintaisia (ks. myös Tickle ym. 2013). Esimerkiksi ymmärrys siitä, mitä tavoitteilla ja arvioinnilla tarkoitetaan ja miten niitä tulkitaan voivat asettaa asiakkaille paineita ja huolia. Kaiken kaikkiaan arviointimenetelmän käyttö vaatii työntekijöiltä herkkyyttä ja kykyä arvioida, mitä käsitteitä asiakkaiden kanssa käytetään, missä kohtaa arviointi on sopivaa tehdä sekä milloin käyttöä tulee perustella ja selittää asiakkaalle tarkemmin (ks. saman tyyppinen havainto tietojärjestelmien käytöstä asiakastilanteissa: Räsänen 2012).

Arviointimenetelmien käyttö säännöllisesti ja tietyin väliajoin ei välttämättä onnistu arkisessa työssä, sillä arviointimenetelmien käytön ja asiakkaan rytmit eivät välttämättä etene samaan tahtiin.Arviointimenetelmien poikkeavaa käyttörytmiä perustellaan myös lyhyillä tukisuhteilla ja asiakkaiden yksilöllisillä tilanteilla (ks. myös Günther ym. 2013). Asiakkaiden arjessa ja elämäntilanteissa on asioita, jotka hoidetaan ennen kuin arviointimenetelmää ryhdytään käyttämään. Asiakkaan kanssa rakennetaan ensin luottamuksellinen suhde sekä pyritään saamaan arki ja elämä jonkinlaiseen järjestykseen (ks. myös Tickle ym. 2013, 198).
Selontekojen analyysi kokonaisuudessaan osoittaa, että arviointimenetelmien käyttämättömyyttä tai odotetusta poikkeavaa käyttöä perustellaan ja oikeutetaan myös arkisen työn luonteella ja reunaehdoilla. Työntekijöiden haastattelupuhe tekee näkyväksi heidän jokapäiväisen työnsä moninaisuuden, joka edellyttää arviointimenetelmien hienovaraista sekä harkinnanvaraista käyttöä asiakkaiden kotiin suuntautuvassa, liikkuvassa työssä. Työskentely asiakkaiden kodeissa edellyttää taitoa ja kykyä arvioida, milloin arviointimenetelmää on sopivaa käyttää. Työskentely asiakkaiden kotiolosuhteissa, heidän yksityisessä tilassaan, vaatii työntekijältä kykyä hallita erilaisia, esimerkiksi vieraan ja ammattilaisen, rooleja (Juhila ym. 2016). Näyttää siltä, että haastatteluun osallistuneet työntekijät ennemmin tasapainottelevat ja sopeuttavat arviointimenetelmien käytön osaksi työtään kuin antavat arviointimenetelmän muovata työkäytäntöjään (ks. Saario 2011). Tulokseni tukevat suositusta siitä, että toimintakykymittareita tulisi käyttää aina perustellusti ja asiakkaan kanssa keskustellen (Manssila ym. 2018).

Tutkimukseni konteksti on hyvin moninainen erilaisine asiakaskuntineen ja arviointimenetelmineen. Silti arviointimenetelmien käyttöön liittyvät jäsennykset ovat melko yhteneväisiä. Toki arviointimenetelmien ja -mittareiden käyttötarkoitus ja niiden sisältämät käsitteet oletettavasti vaikuttavat siihen, miten niistä puhutaan ja miten ne sopivat osaksi arkityötä. Toimintakykymittarithan on aina luotu tiettyä tarkoitusta varten (Voutilainen \& Vaarama 2000, 10). Erilaisia mittareita on runsaasti tarjolla, niiden sisältämät käsitteet ymmärretään eri aloilla eri tavoin (Kivipelto ym. 2013, 19) ja ne myös tuot- 
tavat erilaista tietoa (Sklar ym. 2013). Jatkossa onkin syytä tarkastella tarkemmin arviointimenetelmien eroja siinä, millaista tietoa ne tuottavat ja miten ne palvelevat palveluntuottajien ja palvelun hankinnasta vastaavien organisaatioiden välistä yhteistyötä ja tiedon välitystä.Tällöin tulee keskeiseksi myös eritellä millaisiin taustaolettamuksiin ja käsitteisiin arviointimenetelmät pohjautuvat ja mihin arvioinnilla ja mittaamisella lopulta tietyssä kontekstissa pyritään.

\section{VitTeET}

1 Tutkimukseni kiinnittyy teemallisesti Suomen Akatemian rahoittamaan Kodeissa tapahtuvien palvelukohtaamisten maantiede hyvinvointipalvelujen marginaalissa (2017-2021) -tutkimushankkeeseen, jossa toimin tutkijana. Haluan kiittää tutkimusryhmän jäsenï kaikista tekstiäni koskevista kommenteista.

2 Tuetun asumisen palveluntuottajat saivat itse valita arviointimenetelmän/-mittarin, joka heidän täytyi hyväksyttää tilaajalla.

3 Haastattelupyyntöni oli osoitettu kaikille tuetun asumisen 16:1le palveluntuottajaorganisaatiolle, joista lopulta kahdeksan lupautui haastatteluun. Haastatteluissa oli mukana myös lähiesimiehiä ja tiiminvetäjiä, jotka tekevät asiakastyötä tai toimivat sitä lähellä.

\section{KiRJALlisuUs}

Astamittari/Aspa-säätiö: https://www.aspa. $\mathrm{fi} / \mathrm{fi} /$ laatua-asumiseen/asta- $\% \mathrm{E} 2 \% 88 \% 92$ avuntarpeen-arviointiin Luettu 23.2.2018.

Austin, John L. (1961) Philosophical Papers. Toim. J.O. Urmson, \& G.J. Warnock. Oxford: Clarendon Press.

Baker, Carolyn, D. (2003) Ethnomethodological Analysis of Interviews. Teoksessa James A. Holstein \& Jaber F. Gubrium (toim.) Inside Interviewing: New Lenses, New Concerns. Lontoo: Sage, 395-412.

Clarke, Alan (2006) Evidence-Based Evaluation in Different Professional Domains:
Similarities, Differences and Challenges. Teoksessa Ian Shaw, Jennifer Greene \& Mark Melvin (2006) The SAGE Handbook of Evaluation: Policies, Programs and Practices. Lontoo: Sage, 559-581. https:// doi.org/10.4135/9781848608078.n25

Cree, Viviene E. \& Sumeet, Jain \& Hillen, Peter (2016) The Challenges of Measuring Effectiveness in Social Work: A Case Study of an Evaluation of a Drug and Alcohol Referral Service in Scotland. British Journal of Social Work 46 (1), 277-293. https://doi.org/10.1093/bjsw/bcu118

Garfinkel, Harold (1967) Studies in Ethnomethodology. Cambridge: Polity Press.

GAS-menetelmä: http://www.thl.fi/toimia/tietokanta/mittariversio/150/ Luettu 1.3.2018.

Günther, Kirsi (2015) Asiakasdokumentaatio arviointina mielenterveystyön arjessa: Tutkimus ammatillisesta kirjaamisesta. Tampere:Tampere University Press.

Günther, Kirsi \& Raitakari, Suvi \& Juhila, Kirsi \& Saario, Sirpa \& Kaartamo, Riina \& Kulmala, Anna (2013) Asiakaslähtöisyys vakavaa mielen sairautta sairastavien nuorten aikuisten kuntoutuskurssilla. Etnometodologinen tapaustutkimus. Tampere: Muotialan asuin- ja toimintakeskus ry. Haberer, Jessica \& Trabin, Tom \& Klinkman, Michael (2013) Furthering the reliable and valid measurement of mental health screening, diagnoses, treatment and outcomes through health information technology. General Hospital Psychiatry 35 (4), 349-352. https://doi.org/10.1016/j.genhosppsych.2013.03.009

Hankintasopimus (2015). Tuettu asuminen. Kaupunki X.

Hartswood, Mark \& Procter, Rob \& Rouncefied, Mark \& Slack, Roger (2003) Making a Case in Medical Work: Implications for the Electronic Medical Record. Computer Supported Cooperative Work 12 (3), 241-266. https://doi. org/10.1023/a:1025055829026

Jokinen, Arja \& Juhila, Kirsi \& Raitakari, Suvi (2005) Sosiaalityötä "menestystarinoiden" tuolla puolen? Teoksessa Mirja Satka, Anneli Pohjola \& Marketta Rajavaara (toim.) Sosiaalityö ja vaikuttaminen. Jyväskylä: SoPhi, 149-169.

Juhila, Kirsi \& Hall, Christopher \& Raitakari, Suvi (2010) Accounting for the 
Clients' Troublesome Behaviour in a Supported Housing Unit. Journal of Social Work 10 (1), 59-79. https://doi. org/10.1177/1468017309350657

Juhila, Kirsi \& Hall, Christopher \& Raitakari, Suvi (2016) Interaction during mental health floating support home visits: Managing host-guest and professional-client identities in home spaces. Social and Cultural Geography 17 (1), 101-117. https:// doi.org/10.1080/14649365.2015.104240 1

Kivipelto, Minna \& Saikkonen, Paula (2013) Tiedon tuotanto ja vaikuttavuustieto sosiaalityössä. Yhteiskuntapolitiikka 78 (3), 313-321.

Kivipelto, Minna \& Blomgren, Sanna \& Karjalainen, Pekka \& Saikkonen, Paula (2013) Aikuissosiaalityön vaikuttavuuden arviointimittareiden kehittämisen lähtökohtia. Teoksessa Minna Kivipelto, Sanna Blomgren, Pekka Karjalainen \& Paula Saikkonen (toim.) Vaikuttavaa aikuissosiaalityötä - arviointimalleista mittareihin. Tutkimus- ja kehittämishankkeen loppuraportti. Helsinki:Terveyden ja hyvinvoinnin laitos, 17-26.

Koivula, Anna-Kaarina (2012) Hyvinvointivaikuttavuuden mittaaminen sosiaalipalveluissa. Teoksessa Minna Zechner (toim.) Julkiset sosiaalipalvelut muutoksessa. Markkinat, mittarit ja ennakointi. Seinäjoki:Anja Mäntylän rahasto, 69-90.

Korteniemi, Pertti \& Kotiranta, Tuija \& Kivipelto, Minna (2012) Kokemuksia sosiaalityön vaikuttavuuden arvioinnin toteuttamisesta. Kriittisiä kohtia ja kehittämistarpeita. Teoksessa Anneli Pohjola, Tarja Kemppainen \& Sanna Väyrynen (toim.) Sosiaalityön vaikuttavuus. Rovaniemi: $\mathrm{La}-$ pin yliopistokustannus, 89-115.

Linnakangas, Ritva \& Paasio, Petteri \& Seppälä, Ullamaija \& Suikkanen, Asko (2015) Mitä mittarien käyttö voisi tarjota sosiaalityölle? Janus 23 (4), 405-415.

Living skills -toimintakyvyn ja taitojen arviointityökalu/Living Skills Oy: http:// www.livingskills.fi/ Luettu 1.3.2018.

Lehto, Markku (2004) Toimintakyky terveydenhuollon tulosmuuttujana. Teoksessa Eero Akaan-Penttilä, Tapani Kallanranta, Esko Matikainen, Paavo Rissanen \& Ilpo Vilkkumaa (toim.) Toimintakyky, arviointi ja kliininen käyttö. Helsinki: Duodecim, 18-21.
MacKeith, Joy (2011) The development of the Outcomes star: A participatory approach to assessment and outcome measurement. Housing, Care and Support 14 (3), 98-106. https://doi. org/10.1108/14608791111199778

Manssila, Jaana \& Rahikka, Anne \& Sjöblom, Stina (2018) Suositus toimintakykymittareiden yhdenmukaiseen ja eettiseen käyttöön sosiaalialan asiakastyössä. Helsinki: Terveyden ja hyvinvoinnin laitos.

Mark, Melvin \& Greene, Jennifer \& Shaw, Ian (2006) Introduction: The Evaluation of Policies, Programs and Practices. Teoksessa Ian Shaw, Jennifer Greene \& Mark Melvin (2006) The SAGE Handbook of Evaluation: Policies, Programs and Practices. Lontoo: Sage, 1-28. https://doi. org/10.1108/09504120710775363

Mielenterveys- ja päihdesuunnitelma: Ehdotukset mielenterveys- ja päihdetyön kehittämiseksi vuoteen 2015. Väliarviointi ja toteutumisen kannalta erityisesti tehostettavat toimet (2012) Sosiaali- ja terveysministeriön raportteja 2012: 24. Helsinki: Sosiaali- ja terveysministeriö. https://doi. org/10.26530/oapen_622450

Munro, Eileen (2004) The Impact of Audit on Social Work Practice. British Journal of Social Work 34 (8), 1075-1095. https:// doi.org/10.1093/bjsw/bch130

Paasio, Petteri (2003) Vaikuttavuuden arvioinnin rakenne ja mahdollisuus sosiaalialalla. FinSoc -työpapereita 3/2003. Helsinki: Stakes.

PAAVO, Invalidiliitto: http://www.lapinkuntoutus.fi/portal/fi/toiminta/projektit/ projektiarkisto/paavo-projekti/ Luettu 14.3.18.

Palvelukuvaus (2015) Tuetun asumisen palvelujen hankinta. Kaupunki X.

Pithouse, Andrew \& Hall, Christopher \& Peckover, Sue \& White, Sue (2009) A Tale of Two CAFs:The Impact of the Electronic Common Assessment Framework. British Journal of Social Work 39 (4), 599-612. https://doi.org/10.1093/bjsw/bcp020

Pohjola, Anneli (2012) Moniulotteinen vaikuttavuus. Teoksessa Anneli Pohjola, Tarja Kemppainen \& Sanna Väyrynen (toim.) Sosiaalityön vaikuttavuus. Rovaniemi: Lapin yliopistokustannus, 9-15.

Rajavaara, Marketta (2007) Vaikuttavuusyhteiskunta: Sosiaalisten olojen arvostelusta 
vaikutusten todentamiseen. Sosiaali- ja terveysturvan tutkimuksia 84 . Helsinki: Kelan tutkimusosasto.

Räsänen, Jenni-Mari (2012) Accounting for IT-Based Use of Information in Emergency Social Work Encounters. Nordic Social Work Research 2 (1), 21-37.

Räsänen, Jenni-Mari \& Saario, Sirpa (2017) Welfare workers reflecting their everyday responsibilities in focus groups. Teoksessa Kirsi Juhila, Suvi Raitakari \& Christopher Hall (toim.) Responsibilisation at the Margins of Welfare Services. Lontoo: Routledge, 153-173.

Saario, Sirpa (2011) Arviointitekniikat ja mielenterveystyö - tutkimus ammattilaisten luovinnasta työn arvioinnissa ja seurannassa. Teoksessa Ilpo Helén (toim.) Reformin pirstaleet. Mielenterveyspolitiikka hyvinvointivaltion jälkeen. Tampere: Vastapaino, 182-230

Saario, Sirpa \& Juhila, Kirsi \& Raitakari, Suvi (2015) Boundary work in inter-agency and inter-professional client transitions. Interprofessonal Journal of Care 29 (6), 610-615. https://doi.org/10.3109/13561 820.2015 .1040490

Scott, Marvin, B. \& Lyman, Stanford, M. (1968) Accounts. American Sociological Review 33 (1), 46-62.

Shaw, Ian, \& Mowbray, Carol, T. \& Qureshi, Hazel (2006) Social Work and the Human Services. Teoksessa Ian Shaw, Jennifer Greene \& Mark Melvin (2006) The SAGE Handbook of Evaluation: Policies, Programs and Practices. Lontoo: Sage, 486-511. https://doi. org/10.1108/09504120710775363

Simonen, Mika (2010) Sosiaalisen toimintakyvyn arviointitilanne tutkimushaastattelussa. Gerontologia 24 (2), 187-202.

Simonen, Mika (2017) A Conversation Analysis of Social Interaction in the Functional Capacity Interview.Väitöskirja. Publications of the Faculty of Social Sciences 2017:41. Helsinki: Helsingin yliopisto.

Sklar, Marisa \& Groessl, Erik \& O'Connell, Maria \& Davidson, Larry \& Aarons, Gregory (2013) Intruments for measuring mental health recovery: A systematic review. Clinical Psychology Review 33 (8), 1082-1095. https://doi.org/10.1016/j. cpr.2013.08.002

Sosiaalihuoltolaki 30.12.2014/1301.
Tickle, Anna \& Cheung, Natalie \& Walker, Clare (2013) Professionals' perceptions of the Mental Health Recovery Star. Mental Health Review Journal 18 (4), 194-203. https://doi.org/10.1108/mhrj-04-20130015

Tobias, Glen (2010) Mental health outcome measurement in non-government organizations (NGOs). Teoksessa Tom Trauer (toim.) Outcome Measurement in Mental Health: Theory and Practice. Cambridge: Cambridge University Press, 164-172. https://doi.org/10.1017/ cbo9780511760686.017

TOIMIA. Toimintakyvyn mittaamisen ja arvioinnin kansallinen asiantuntijaverkosto. http://www.thl.fi/toimia/tietokanta/ Luettu 26.6.2017.

Toipumistähti, mielenterveyskuntoutujan tulostähti/Uusia Network: http://www.uusianetwork.fi/tulostahti/tulostahdet Luettu 2.3.2018

Trauer, Tom (2010) Outcome measurement: Applications and utility. Teoksessa Tom Trauer (toim.) Outcome Measurement in Mental Health:Theory and Practice. Cambridge: Cambridge University Press, 185-195. https://doi.org/10.1017/ cbo9780511760686.019

Tuva ${ }^{\circledR}$ - toimintakykymittari/Finnish Consulting Group Oy: http://www.fcg.fi/tuva Luettu 23.2.2018.

Voutilainen, Päivi \& Vaarama, Marja (2004) Toimintakykymittareiden käyttö ikääntyneiden palvelutarpeen arvioinnissa. Raportteja 7/2004. Helsinki: Stakes.

Väyrynen, Sanna (2012) Muutosta edistävät tekijät päihde- ja mielenterveyskuntoutuksessa. Asiakkaiden kokemuksia intensiivisen avokuntoutuksen vaikuttavuudesta. Teoksessa Anneli Pohjola, Tarja Kemppainen \& Sanna Väyrynen (toim.) Sosiaalityön vaikuttavuus. Rovaniemi: Lapin yliopistokustannus, 271-300.

WHODAS 2.0, World Health Organization Disability Assessment Schedule: http://www.who.int/classifications/icf/ WHODAS2.0_36itemsSELF.pdf Luettu 1.3.2018.

Winter, Karen \& Cree, Viviene (2016) Social Work Home Visits to Children and Families in the UK: A Foucauldian Perspective. British Journal of Social Work 46 (5), 1175-1190. https://doi.org/10.1093/ bjsw/bcv069 